\title{
High folic acid diet enhances tumour growth in PyMT-induced breast cancer
}

\author{
Mariann Fagernæs Hansen ${ }^{1}$, Sarah Østrup Jensen ${ }^{1}$, Ernst-Martin Füchtbauer ${ }^{1}$ and Pia M Martensen ${ }^{\star}, 1$ \\ ${ }^{1}$ Department of Molecular Biology and Genetics, Aarhus University, Aarhus C 8000, Denmark
}

\begin{abstract}
Background: The B-vitamin folate is among the most studied bioactive food compound, and a dietary intake meeting the daily requirements has been found to reduce the risk of cancer and cardiovascular diseases as well as preventing neural tube defects during fetal development. Several countries have therefore introduced dietary fortification with folic acid. However, clinical and animal studies suggest that folic acid has a dual role in cancer development.
\end{abstract}

Methods: During the period of initial tumour progression, MMTV-PyMT (MMTV-polyoma virus middle T) transgenic mice were fed with normal diet and high folic acid diet.

Results: We found that PyMT-induced breast tumours highly express the cancer-specific folate receptor (FR), a feature they share with several human epithelial cancers in which expression of FR $\alpha$ correlates with tumour grade. Mice receiving a high folic acid diet displayed a significantly increased tumour volume compared with mice receiving normal diet. In the largest tumours, only found in mice on high folic acid diet, STAT3 was activated. In primary cells from PyMT tumours, STAT3 was activated upon treatment with folic acid in culture.

Conclusions: Our results offer a novel molecular explanation for folic acid-induced growth of existing tumours.

Folates are a group of B vitamins that share a common vitamin activity based on the tetrahydrofolate structure. Folic acid is a highly stable synthetic, oxidised folate used for vitamin supplements and fortified foods (Finglas et al, 2003; Strickland et al, 2013). Humans are not able to produce folates and depend on food intake from mainly cereals and leafy vegetables to meet the daily requirements of $\sim 400 \mu \mathrm{g}$ as defined by the Food and Nutrition Board of the Institute of Medicine, National Academy of Sciences. Folates are transported across the mucosal lining of the digestive tract mainly by the low $\mathrm{pH}$ folate transporter (Zhao et al, 2004, 2011). Serum folates can be taken up by cells through the reduced folate carrier (RFC) present on most cells, or by high-affinity cellspecific folate receptors (FRs) including the human $\operatorname{FR} \alpha, \operatorname{FR} \beta$ and FR $\delta$ (Kelemen, 2006; Zhao et al, 2008). The human FR family of receptors also include the soluble $\mathrm{FR} \gamma$ receptor. Inside the cells, folates act as a one-carbon donor in important metabolic pathways including the biosynthesis of nucleotides and methionine (Lucock, 2000; Finglas et al, 2003; Miller et al, 2008).

The ubiquitously expressed RFC has a high affinity for naturally occurring folates, whereas the cell-specific FR $\alpha$ has a higher affinity for the synthetic folic acid (reviewed in Kelemen (2006)). Folate receptor- $\alpha$ is the best characterised of the human FRs. It is linked to the membrane through a glycosylphosphatidylinositol anchor, and presumably mediates the transport of folic acid by receptormediated endocytosis (Kamen et al, 1988; Smart et al, 1996; Sabharanjak and Mayor, 2004; Birn, 2006; Elnakat et al, 2009). Folate receptor- $\alpha$ expression is restricted to epithelial cells with a high expression in the kidney, placenta, lung and the choroid plexus (Elnakat and Ratnam, 2004; Parker et al, 2005; Kelemen, 2006). In addition, $F R \alpha$ is highly expressed on the surface of several epithelial cancer types including colon, breast and ovarian cancers. Ovarian cancers are among the cancer types with the highest FR $\alpha$ expression, and a correlation between the tumour grade and FR $\alpha$ expression has been observed (Parker et al, 2005; Chen et al, 2012). A recent and very comprehensive analysis using ovarian tissue microarray analyses combined with mRNA levels from the Cancer Genome Atlas showed that FR $\alpha$ is also expressed in normal tissue from the fallopian tubes and on the surface of ovarian epithelial cells (Kobel et al, 2014). In addition, these authors found an increased 2-year overall survival for high-grade serous ovarian

*Correspondence: Dr PM Martensen; E-mail: pmm@mbg.au.dk

Received 1 August 2016; revised 20 December 2016; accepted 5 January 2017; published online 2 February 2017

(C) 2017 Cancer Research UK. All rights reserved 0007 - 0920/17 
carcinomas (FIGO stage I/II tumours) when FR $\alpha$ levels were high. This was in contrast to ovarian clear-cell carcinomas, in which high $\mathrm{FR} \alpha$ levels correlated with a decreased progression-free survival independent of follow-up time. However, the physiological function of $\mathrm{FR} \alpha$ in cancer is still elusive, as folate uptake in ovarian cancer cells expressing high levels of FR $\alpha$ was found to be primarily mediated by the RFC and intracellular accumulation of folates in the ovarian cancer cell line IGROV-1 and the human kidney epithelial cell line HK2 was not primarily dependent on FR $\alpha$ (Corona et al, 1998; Kamen and Smith, 2012).

Folate deficiency during pregnancy increases the risk of neural tube defects, which has led several countries including the United States and Canada to demand that cereal products are fortified with folic acid (Finglas et al, 2003; Kelemen, 2006; Strickland et al, 2013). When comparing the incidence of colorectal cancer in the United States and Canada after the fortification period, an increase in the incidence of colorectal cancer was seen (Mason et al, 2007); however, many other explanations for this increase can be put forward. In fact, a recent meta-analysis investigating placebocontrolled folate treatments and the occurrence of cancer found no relationship between folate treatment and several types of cancers including colon and breast cancer (Qin et al, 2013; Vollset et al, 2013). Interestingly, in a mouse model of colon cancer, it was found that folic acid supplementation before the establishment of neoplastic foci was tumour preventing, whereas folic acid supplementation after the establishment of neoplastic foci was tumour promoting (Song et al, 2000). The tumour-preventive effects of folic acid supplementation can be explained by the fact that excess folic acid increase DNA repair in healthy tissues, thereby preventing cancer, and the tumour-promoting effect is explained by the fact that the high levels of DNA replication in cancer tissues require high levels of folic acid for continued tumour growth (Miller et al, 2008).

In the polyoma virus middle $\mathrm{T}$ (PyMT) breast cancer mouse model, the PyMT oncogene is expressed in the mammary epithelium under the control of mouse mammary tumour virus - long terminal repeat promoter element (Guy et al, 1992). When expressed, the middle T (MT) protein is inserted into the cell membrane and undergoes phosphorylation by kinases of the Src family, thereby activating oncogenic cell signalling (Fluck and Schaffhausen, 2009). This causes the development of palpable mammary carcinomas with $100 \%$ penetrance within 6-8 weeks in PyMT hemizygous females. Already at 4 weeks of age hyperplasia can be detected followed by adenomas, then progression to lowand high-grade carcinomas and eventually pulmonary metastasis at $\sim 14$ weeks of age (Lin et al, 2003). Gene expression studies of PyMT breast tissues have confirmed a very uniform gene expression profile for individual tumours and a high similarity to human luminal breast cancer (Herschkowitz et al, 2007). The high consistency and predictability of tumour occurrence makes the PyMT transgenic mouse a good model for studying breast tumour growth and progression.

In this study, we investigated the effect of a high folic acid diet $\left(10 \mathrm{mg} \mathrm{kg}^{-1}\right)$ with that of a normal folic acid diet $\left(2 \mathrm{mg} \mathrm{kg}^{-1}\right)$ on tumour growth in the PyMT mouse model. Furthermore, possible signalling pathways responsible for tumour growth were investigated. Moreover, expression of the murine FR in the PyMT mouse model was investigated because it is the homolog of the human $\mathrm{FR} \alpha$, which is highly expressed in numerous malignant tissues including breast cancers.

\section{MATERIALS AND METHODS}

Mice. FVB/N-Tg (MMTV-PyVT)634Mul/J mice (here called PyMT) (Guy et al, 1992) were obtained from Dr Lars Engelholm
(The Finsen Laboratory, Copenhagen, Denmark). The wild-type (wt) FVB/N mice were obtained from Taconic (Ejby, Denmark). Polyoma virus middle $\mathrm{T}$ males were mated with $\mathrm{FVB} / \mathrm{N}$ females to generate a PyMT hemizygous female study population. All animal experiments were performed following the regulations of the National Danish Authorities with the permission no.: 2012-152935-00002. The PyMT mice were palpated two times a week to survey tumour progression.

Genotyping. DNA was extracted from the tail tip or ear clippings and subjected to PCR analyses to determine the PyMT status as described previously (Bugge et al, 1998).

Diet. All mice were fed a standard maintenance diet with $2 \mathrm{mg}$ folic acid per kg added (Altromin 1324, Brogaarden, Denmark), which fulfills the normal folate requirements for rodents. The content of Altromin 1324 is listed in Table 1, and the amount of folate from other sources in the diet was stated as $0.335 \mathrm{mg} \mathrm{kg}^{-1}$. For the diet intervention study, some of the mice were fed a diet with $8 \mathrm{mg} \mathrm{kg}^{-1}$ extra folic acid added, that is, in total $10 \mathrm{mg}$ folic acid per $\mathrm{kg}$ together with the $0.335 \mathrm{mg}$ folate per $\mathrm{kg}$ (Altromin 1324). This high folic acid diet contains five times the daily requirements (Song et al, 2000). The control FVB/N mice were fed the standard rodent diet with $2 \mathrm{mg}$ folic acid per $\mathrm{kg}$ added. Animals had access to food and water ad libitum.

For the diet intervention study, female PyMT littermates were weaned at 23 days of age and randomised to receive a diet with either the normal $2 \mathrm{mg}$ folic acid per $\mathrm{kg}$ or the high $10 \mathrm{mg}$ folic acid per $\mathrm{kg}$ added (in total $N=11$ and 10 , respectively). These mice were killed at day 62 using cervical dislocation. Control wt FVB/N mice were kept on the standard rodent diet with $2 \mathrm{mg}$ folic acid per $\mathrm{kg}$ and killed at day $62(N=2)$.

For the protein expression study, PyMT and wt FVB/N female littermates were fed the standard rodent diet with $2 \mathrm{mg} \mathrm{kg}^{-1}$ folic acid before being killed at 3 to 9 weeks of age.

Tissue dissection. All 10 mammary glands from each animal in the diet intervention study group were dissected and tumour volume (length $\times$ width $\times$ height) was measured by an automated calliper. Tumours from the left side of the mouse were processed for immunohistochemistry, and tumours from the right side of the mouse were processed for immunoblot analysis. From PyMT and wt FVB/N littermates between 3 and 9 weeks of age, all mammary glands were dissected and kept for immunoblot analyses or RNA extractions. Kidney and heart tissues were dissected as controls $(N=2)$.

Tissue $\left(50-100 \mathrm{~mm}^{3}\right)$ for immunoblot analysis was diced and placed in $400 \mu \mathrm{l}$ ice-cold homogenisation buffer $(10 \mathrm{~mm}$ Tris- $\mathrm{HCl}$ (pH 7.5) with $1 \mu \mathrm{lml}^{-1}$ Protease Inhibitor Cocktail (Sigma, Brøndby, Denmark) and $1 \mu \mathrm{ml}^{-1}$ Phosphatase Inhibitor (Sigma)). Samples were homogenised using a Polytron PT 1200E (Kinematica AG, Luzern, Schwitzerland) with aggregate PT-DA 07/2 SYN-E082. Samples were centrifuged at $1500 \mathbf{g}$ and total protein concentration was measured using a BCA assay (Pierce, Thermo Scientific, Rockford, IL, USA). Lysis buffer was added to a final concentration of $62.5 \mathrm{~mm}$ Tris- $\mathrm{HCl}(\mathrm{pH} 7.5), 2 \%$ SDS and $10 \%$ glycerol and incubated overnight at $4{ }^{\circ} \mathrm{C}$ with $0.5 \mu \mathrm{l} / 100 \mu \mathrm{l}$ benzonase (Merck, Brøndby, Denmark). Protein extracts were cleared by centrifugation $13000 \mathrm{~g}$ for $10 \mathrm{~min}$.

Isolation of cells from PyMT tumours and folic acid treatment. Mammary gland tumour tissues were dissected from a hemizygous female PyMT mice at day 62 and kept in RPMI 1640 without folic acid but with $10 \%$ foetal bovine serum (FBS) (Invitrogen, Thermo Fisher Scientific, Paisley, UK), and $100 \mathrm{U} \mathrm{ml}^{-1}$ penicillin/ $100 \mu \mathrm{g} \mathrm{ml}^{-1}$ streptomycin (Invitrogen). Fibrous tissue was removed and the tumours were cut into 3 to $4 \mathrm{~mm}$ pieces in $35 \mathrm{~mm}$ dishes. The tumour pieces were washed three times with $\mathrm{Ca}^{2+}$ - and $\mathrm{Mg}^{2+}$-free phosphate-buffered saline (PBS) before $5 \times$ 
Table 1. Content of Altromin 1324 standard diet

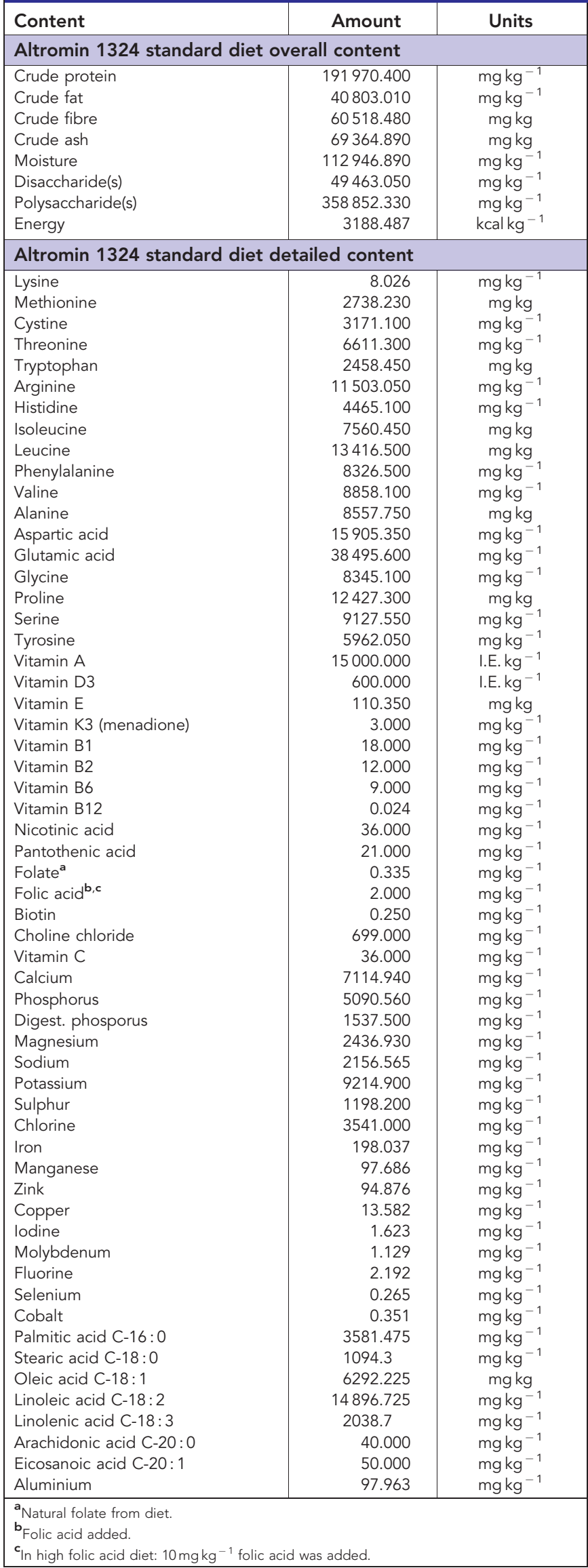

trypsin-EDTA (Invitrogen) was added to each dish and incubation for $6 \mathrm{~h}$ at $4{ }^{\circ} \mathrm{C}$ allowed the trypsin to penetrate into the tissue. The trypsin was decanted and the tissue was incubated at $37^{\circ} \mathrm{C}$ for 30 min to allow trypsin digestion. Prewarmed RPMI 1640 without folic acid but with $10 \% \mathrm{FBS}$, and $100 \mathrm{U} \mathrm{ml}^{-1}$ penicillin/ $100 \mu \mathrm{g} \mathrm{ml}^{-1}$ streptomycin was added to the cells followed by a centrifugation at $50 \mathrm{~g}$ for $1 \mathrm{~min}$ to remove undissociated tissue fragments. Collection of single cells was carried out by centrifugation at $100 \mathrm{~g}$ for $2 \mathrm{~min}$, and $0.5 \times 10^{6}$ cells were seeded per well in a 12 -well plate. The following day, cell media were changed to media without folic acid containing 10\% charcoal-filtered FBS, and $100 \mathrm{U} \mathrm{ml}^{-1}$ penicillin $/ 100 \mu \mathrm{g} \mathrm{ml}^{-1}$ streptomycin. Cells were treated with 500,300 or $0 \mu \mathrm{g} \mathrm{ml}^{-1}$ folic acid for $12 \mathrm{~min}$ before cells were washed in PBS and lysed in a lysis buffer $(62.5 \mathrm{~mm}$ Tris$\mathrm{HCl}(\mathrm{pH} 7.5), 2 \%$ SDS and $10 \%$ glycerol added protease inhibitor cocktail (Sigma) and phosphatase inhibitor cocktail (Sigma)) and incubated overnight at $4{ }^{\circ} \mathrm{C}$ with $0.5 \mu \mathrm{l} / 100 \mu \mathrm{l}$ benzonase (Merck). Protein extracts were cleared by centrifugation at $13000 \mathrm{~g}$ for $10 \mathrm{~min}$ and kept at $-80^{\circ} \mathrm{C}$.

Chemicals, reagents and antibodies. Antibodies against STAT3, phospho-STAT3(Y705) XP (pSTAT3), ERK1/2 and phosphoERK1/2 (pERK1/2) were all raised in rabbit and purchased from Cell Signalling (Beverly, MA, USA). The antibody against actin was raised in goat and purchased from Santa Cruz Biotechnology (Dallas, TX, USA). The antibody against murine FR was kindly donated by Dr Henrik Birn (Birn et al, 2005). The horseradish peroxidase-conjugated polyclonal goat anti-rabbit immunoglobulins were purchased from DakoCytomation (Glostrup, Denmark), and the horseradish peroxidase-conjugated polyclonal rabbit antigoat immunoglobulins were from Santa Cruz Biotechnology. The Alexa Fluor 488 goat anti-rabbit immunoglobulins were from Molecular Probes (Thermo Fisher Scientific, Paisley, UK).

Immunoblot analysis. For immunoblot analysis $25 \mu \mathrm{g}$ of protein extracts were dissolved in $1 \times$ Laemmli buffer $(58 \mathrm{~mm}$ Tris- $\mathrm{HCl}$ ( $\mathrm{pH}$ 6.8), $1.7 \%$ SDS, 5\% glycerol, $1.6 \%$ dithiothreitol, $0.01 \%$ bromophenol blue), except for detection of FR in which SDSPAGE was performed under non-reducing conditions. Proteins were resolved on $10 \%$ acrylamide gels and the proteins were transferred to PVDF membranes (Millipore, Billerica, MA, USA). ECL Plus Western Blotting Detection System (GE Healthcare, Buckinghamshire, UK) was used for visualisation of protein bands. Blots were stripped for successive antibody probes using a strip buffer ( $82 \mathrm{~mm}$ Tris-HCl (pH 6.7), 2\% SDS, 100 mм $\beta$-mercaptoethanol). Immunoblot densitometry was performed using Adobe Photoshop version CS5 (San José, CA, USA).

Immunohistochemistry. Mouse mammary gland tissues and control heart and kidney tissues were fixed in freshly diluted $4 \%$ paraformaldehyde (single-use glass vials from Bie and Berntsen) in PBS) overnight. Tissues were washed four times for $1 \mathrm{~h}$ before snap freezing on a metal block on dry ice and kept at $-80^{\circ} \mathrm{C}$. Before cryosectioning on a Leica CM 1100 Cryosectioner (Wetzlar, Germany), the tissue was equilibrated to $-20{ }^{\circ} \mathrm{C}$ and embedded in Tissue-Tek OCT Compound (Sakura Finetek Europe BV, Alphen aan den Rijn, The Netherlands). Sections of $10 \mu \mathrm{m}$ were cut and transferred to Superfrost plus microscope slides (Menzel Glaser, Braunschweig, Germany). After air-drying for $30 \mathrm{~min}$, slides were washed three times for $5 \mathrm{~min}$ in Tris-buffered saline (TBS) before permeabilisation in TBS containing $0.1 \%$ Triton $\mathrm{X}-100$ (TBS-T) for $10 \mathrm{~min}$. When using antibodies against pSTAT3, tissues were pretreated after the first wash with $1 \%$ SDS in TBS for $5 \mathrm{~min}$ to denature proteins, as described previously (Brown et al, 1996; Garcia et al, 1997). Slides were blocked for $1 \mathrm{~h}$ at room temperature in blocking solution (TBS-T containing 3\% 
BSA) before incubation with primary antibodies in the blocking solution. The following day, slides were washed four times for $10 \mathrm{~min}$ in TBS-T before incubation with Alexa Fluor 488conjugated secondary antibody diluted in blocking solution for $2 \mathrm{~h}$. Slides were washed two times in TBS-T and two times in TBS before mounting using ProLong Gold Antifade Reagent with DAPI (Invitrogen). Slides were visualised using a Leica CM100 microscope and a DFC 425C camera (Wetzlar, Germany) and images were processed using Adobe Photoshop version CS5.

RT-PCR. RNA was purified from mammary gland tissues from PyMT and wt FVB/N mice with TRIzol Reagent (Invitrogen) according to the manufacturer's instructions. One millilitre of TRIzol Reagent was used for $60-80 \mathrm{mg}$ tissue and samples were homogenised using a VWR Pellet Mixer (VWR International, Radnar, PA, USA). The RNA concentration was determined by absorbance measurements at $260 \mathrm{~nm}$ using a $\mu$ Quant reader (Biotek Instruments Inc., Winooshi, VT, USA). Using $1 \mu \mathrm{g}$ RNA, cDNA was synthesised with M-MLV reverse transcriptase (Invitrogen) using oligo (dT) primers according to the manufacturer's instructions. PCR analyses were carried out with Taq polymerase (Invitrogen) in a total reaction volume of $20 \mu \mathrm{l}$ in $1 \times$ reaction buffer with $250 \mathrm{~nm}$ dNTPs, $1.5 \mathrm{~mm} \mathrm{MgCl}_{2}, 4 \% \mathrm{DMSO}$, $1 \mathrm{~m}$ betaine and $1 \mu \mathrm{M}$ each of the primers. PCR cycling conditions were an initial denaturation step at $94^{\circ} \mathrm{C}$ for $5 \mathrm{~min}$, followed by 30 cycles of: $30 \mathrm{~s}$ at $94{ }^{\circ} \mathrm{C}, 45 \mathrm{~s}$ at $53^{\circ} \mathrm{C}$ (for RPLP0) or $58^{\circ} \mathrm{C}$ (for FR and MT), and $1 \mathrm{~min}$ at $72{ }^{\circ} \mathrm{C}$, followed by a final elongation step at $72^{\circ} \mathrm{C}$ for $10 \mathrm{~min}$. The primers used were as follows: FR-fwd, $5^{\prime}$-GACAATTTACACGACCAGT- ${ }^{\prime}$ and FR-rev: 5' -GTTCCATCC CTTGTGCCA-3'; RPLP0-fwd, 5'-GATGCCCAGGGAAGACAG-3' and RPLP0-rev, 5'-ACAATGAAGCATTTTGGATAATCA-3'; MT-fwd, 5'-CTGCTACTGCACCCAGACAA- $3^{\prime}$ and MT-rev, 5'-GCAGGTAAGAGGCATTCTGC-3'. PCR products were visualised by $2 \%$ agarose gel electrophoresis in TBE buffer (Invitrogen), using GeneRuler 100 bp Plus DNA ladder (Fermentas, Vilnius, Lithuania) as a marker.

\section{RESULTS}

For the diet intervention study, female hemizygous PyMT mice were subjected to intervention after weaning at day 23. Randomly selected littermates remained either on a standard folic acid diet $\left(2 \mathrm{mg} \mathrm{kg}^{-1}\right)$ or a high folic acid diet $\left(10 \mathrm{mg} \mathrm{kg}^{-1}\right)$ until killing at day 62 (9 weeks old). Mammary gland tissues were dissected and the total volume was determined for each mouse. Polyoma virus middle $\mathrm{T}$ mice fed the high folic acid diet had an almost double (1.9-fold) total tumour volume per mouse compared with mice fed a normal diet $(1641 \pm 138$ vs $843 \pm 83 \mathrm{~mm}^{3}, P<0.0001$; Figure 1A). To investigate how the increased tumour volume was distributed, the volume of individual tissues was determined. Normal breast tissue from wt $\mathrm{FVB} / \mathrm{N}$ mice has been determined to be $\sim 100 \mathrm{~mm}^{3}$ (unpublished observation). Polyoma virus middle $\mathrm{T}$ mice fed the high folic acid diet had a 1.9-fold increase in the number of tumours above $100 \mathrm{~mm}^{3}$ compared with PyMT mice fed the standard diet $\left(6.20 \pm 0.9\right.$ vs $3.2 \pm 0.6 \mathrm{~mm}^{3}, P=0.01$; Figure 1B). Furthermore, PyMT mice fed the high folic acid diet had an 11-fold increase in the number of tumours above $200 \mathrm{~mm}^{3}$ compared with mice fed a normal diet $(2.2 \pm 0.4$ vs $0.2 \pm 0.2 \mathrm{~mm}^{3}, P=0.0003$; Figure $\left.1 \mathrm{~B}\right)$. In conclusion, the high folic acid diet led to an increased total tumour volume and an increased number of large tumours.

The FR and activated STAT3 is highly expressed in tumour tissue. As FR $\alpha$ is highly expressed in numerous human cancers including breast cancers (Parker et al, 2005; Zhang et al, 2013), we initially investigated the expression of murine FRs in breast tumours from PyMT mice from the intervention studies. Immunoblot analysis demonstrated that murine FR was present in all but one of the breast tumours from PyMT mice, and FR was absent in all normal wt FVB/ $\mathrm{N}$ breast tissue from 9-week-old mice (Figure 2A). The one tumour sample marked with an asterisk, which did not show any expression of murine FR, was hampered by a high level of red blood cell contamination. A high expression of FR in kidney tissues and no expression in heart tissues confirmed the specificity of the antibody, which has also been confirmed in FR knockout mice (Birn et al, 2005). We found no difference in murine FR levels in PyMT-induced tumours of either different size or from animals receiving different diet. Immunohistochemistry confirmed the expression of FR in the cancer cells in the breast tumours with a membrane and/or cytoplasmic localisation (Figure 3).

The MT antigen is a membrane-bound protein, which interacts with signalling molecules leading to constitutive activation of MAP kinase pathways. To investigate if the MAP kinase ERK1/2 were involved in the tumour development, we performed
A

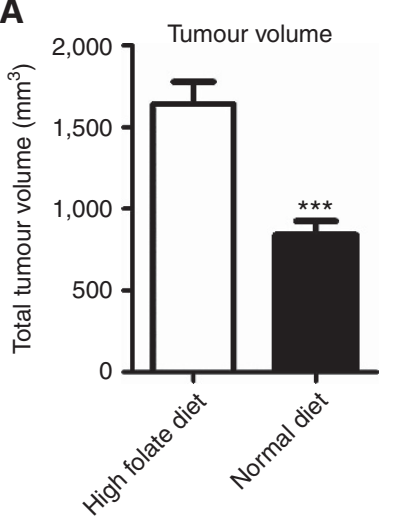

B

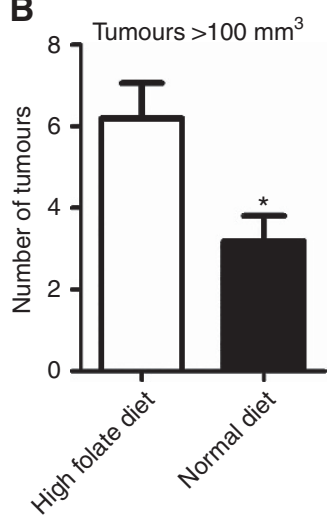

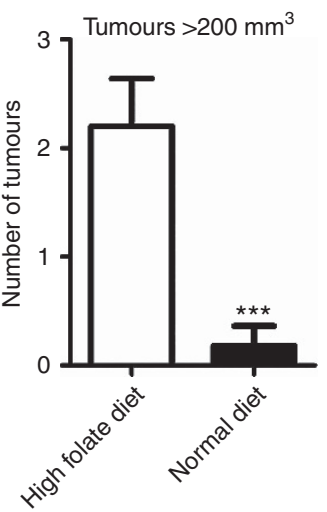

Figure 1. A high folic acid diet increases the total tumour volume and the number of tumours in PyMT transgenic mice. Polyoma virus middle T transgenic female mice received a standard rodent diet (with $2 \mathrm{mg}$ folic acid per kg added, $N=11$ ) or a high folic acid diet (with $10 \mathrm{mg}$ folic acid per $\mathrm{kg}$ added, $N=10$ ) from day 23 to day 62 where they were killed. From each mouse, 10 breast tissues were dissected and the volume was measured. (A) The average tumour volume per mouse is shown for each group. Student's t-test: $\star \star \star P<0.0001$. (B) The average number of tumours from each mouse with a volume above 100 and $200 \mathrm{~mm}^{3}$ were counted and the average number per mouse is shown for each group. Student's t-test: ${ }^{\star} P=0.01,{ }^{* \star *} P=0.0003$. 
A

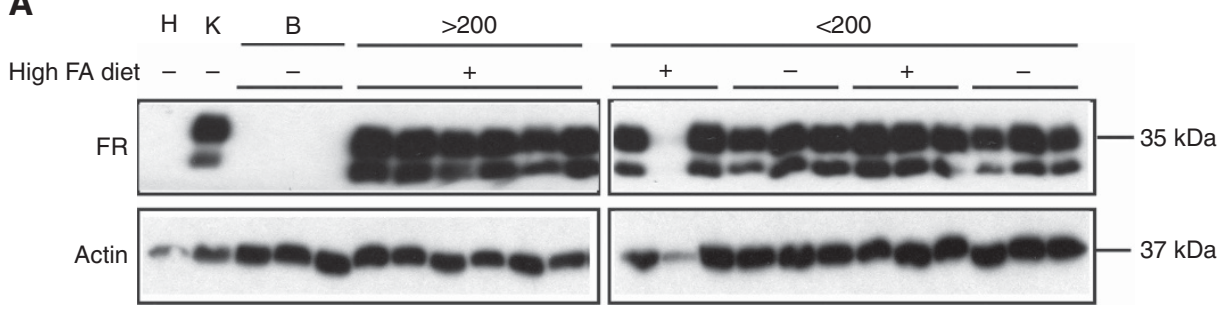

B

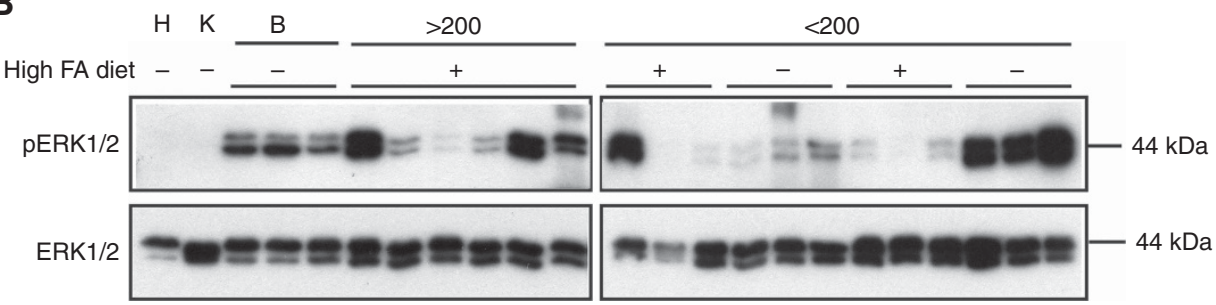

C
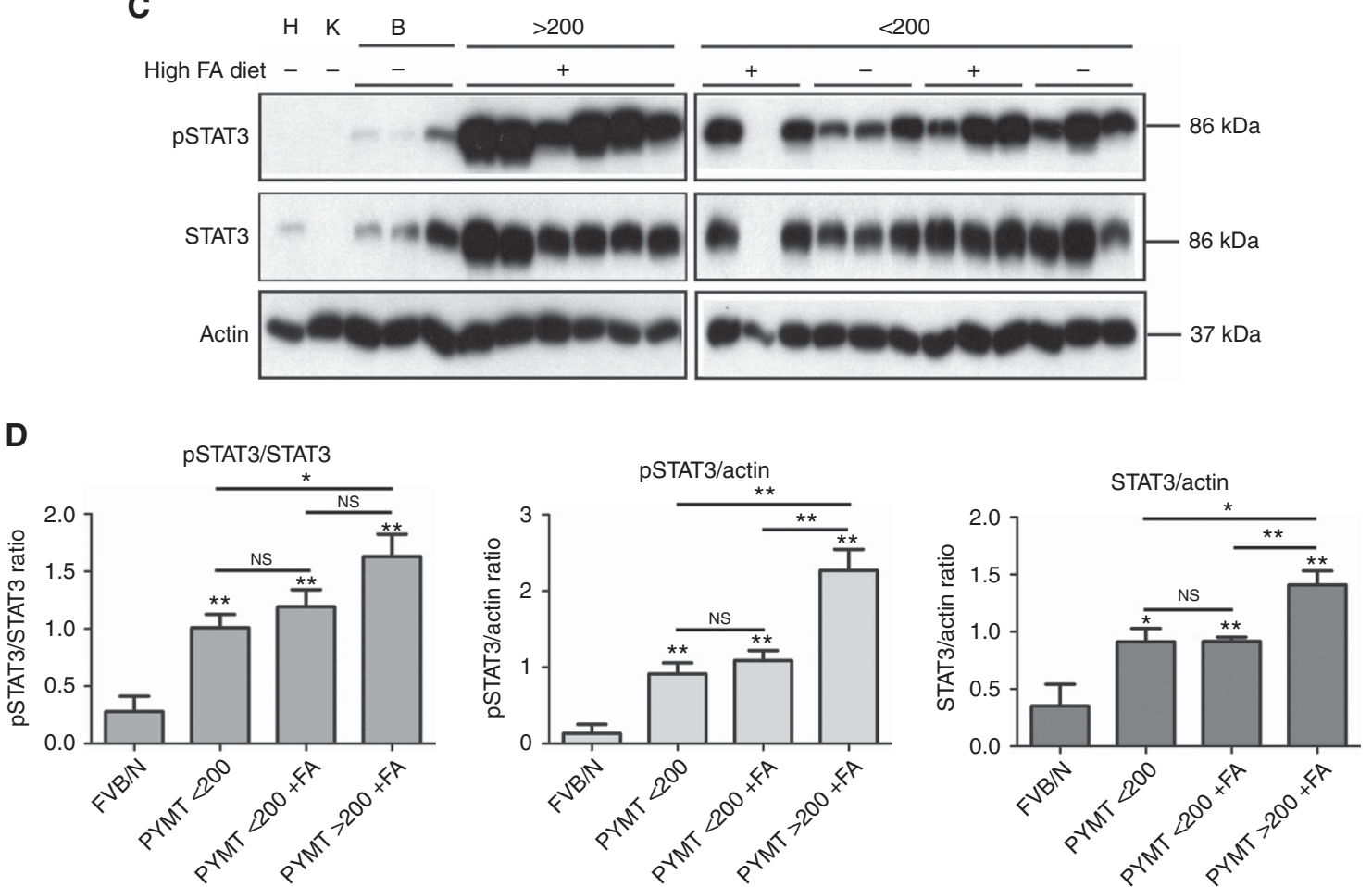

Figure 2. Protein expression in PyMT tumours. Randomly selected protein extracts from 9-week-old PyMT tumours were divided into groups according to tumour size (below or above $200 \mathrm{~mm}^{3}$ ) and diet with high (+) or normal (-) folic acid (FA). Control tissue: $\mathrm{H}$, heart, $\mathrm{K}, \mathrm{kidney} ; \mathrm{B}$, wt FVB/N breast tissue. The sample marked with an asterisk was not included in the analysis. (A-C) Protein extracts from the individual tumours and control tissues were loaded on the gel, and immunoblot analysis was performed by using antibodies raised against the indicated proteins. Actin was used as a loading control. Sodium dodecyl sulphate-polyacrylamide gel electrophoresis for the FR was performed under non-reducing conditions. (D) Immunoblot densitometry was performed, and the PSTAT3/STAT3, pSTAT3/actin and STAT3/actin ratios were determined. The values were normalised to protein extracts loaded on both gels serving as internal controls between gels. Statistical analyses using Student's $t$-test were performed (GraphPad Prism, La Jolla, CA, USA) with the following groups: FVB/N $(N=3)$, PyMT $<200(N=6), P y M T<200+F A(N=5)$ and PyMT $>200+F A(N=6) .{ }^{*} P<0.01,{ }^{*} P<0.05$ and $N S$, not significant.

immunoblot analysis against phosphorylated ERK1/2 (Figure 2B). Extracellular signal-regulated kinase1/2 was found to be phosphorylated in the normal breast tissue, and to a varying degree in the tumours. However, there seemed to be no pattern in the phosphorylation status of ERK1/2 compared with tumour size or folate status.

As STAT3 is known to be highly activated during transformation by the MT antigen (Fluck and Schaffhausen, 2009; Guo et al, 2011), we investigated if folic acid treatment or tumour size affected STAT3 activation (Figure 2C). Immunoblot analysis showed an increased STAT3 activation in PyMT tumours compared with normal breast tissue. However, the total amount of STAT3 was also increased in the tumours. Immunoblot analysis using an anti-actin antibody confirmed equal amount of protein in each lane. Quantification of protein bands showed a significant increase in pSTAT3 levels both relative to STAT3 levels and relative to actin levels in PyMT mice compared with control FVB/N mice (Figure 2D). Also, total STAT3 levels 

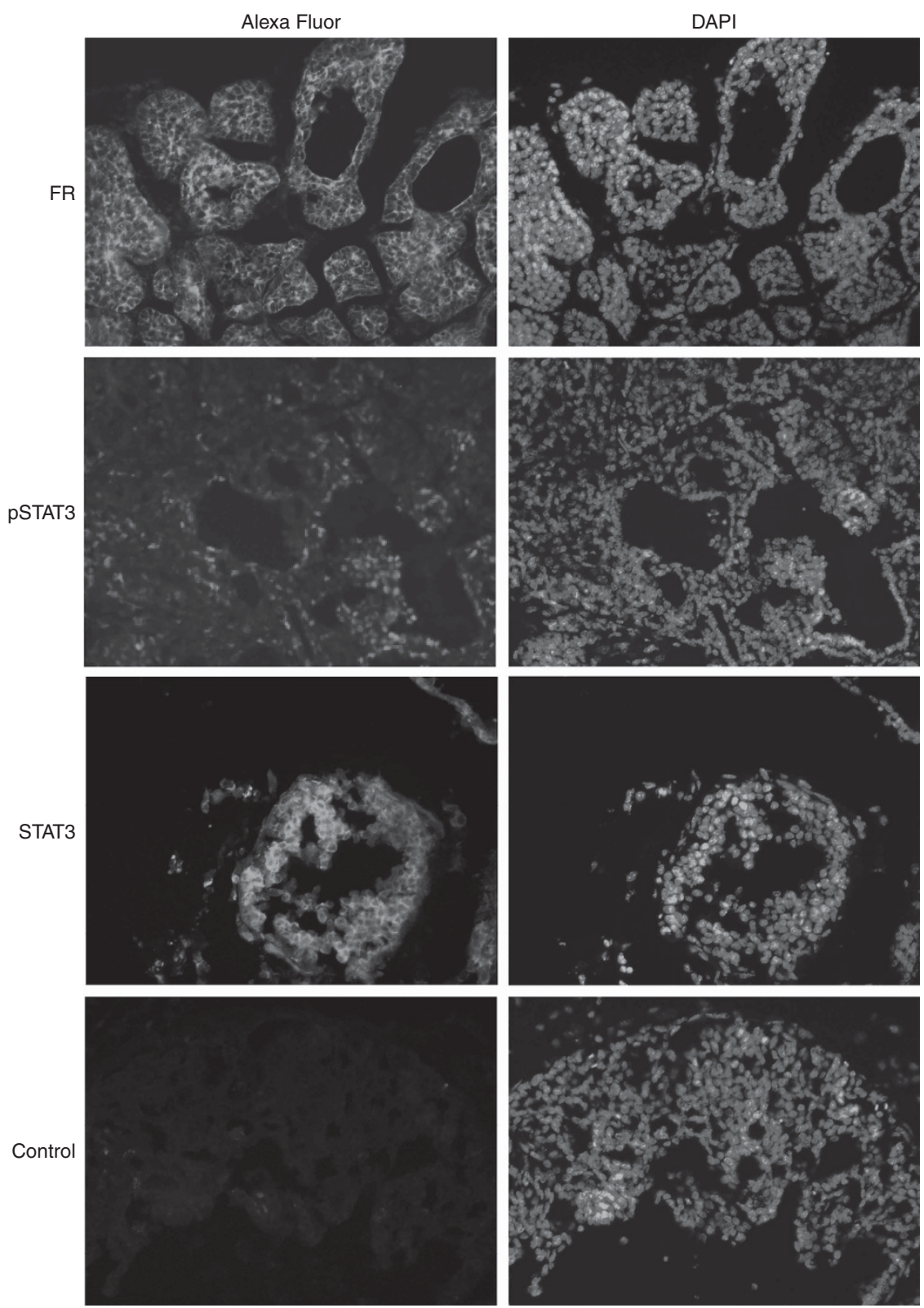

Figure 3. Polyoma virus middle T cancer cells express activated STAT3 and FR. Immunofluorescent histochemical staining of breast tissue sections from 9-week-old PyMT female mice was performed using antibodies specific for the indicated proteins. The control was incubated with bovine serum albumin (BSA) blocking solution alone, followed by incubation with the secondary antibody. Alexa Fluor (green) is Alexa Fluor-488conjugated secondary antibody. The nuclei (blue) is stained with DAPI (4',6-diamidino-2-phenylindole). Pictures were processed using Adobe Photoshop CS5. A full color version of this figure is available at the British Journal of Cancer journal online.

were increased in breast tissue from PyMT mice compared with control mice. A significant increase in total STAT3 levels was observed in tumours $>200 \mathrm{~mm}^{3}$ compared with smaller tumours. No difference in pSTAT3 levels were seen between tumours from mice receiving a normal diet or high folic acid diet in the tumours $<200 \mathrm{~mm}^{3}$. Notably, only one tumour above $200 \mathrm{~mm}^{3}$ was found in a mice fed a normal diet, and none from the left side of the mice preserved for immunoblot analysis. Immunofluorescence staining for pSTAT3 showed STAT3 activation in the tumour cells (Figure 3). Not all tumour cells had activated STAT3, but all cells expressed STAT3. In some tumour cells, a nuclear translocation of total STAT3 was seen further indicating STAT3 activation.

Folic acid activates STAT3 in PyMT primary cells. We have previously shown that folic acid can activate STAT3 in the human cervical carcinoma (HeLa) human cancer cell line via the human FR $\alpha$ (Hansen et al, 2015). To evaluate if the increase in STAT3 activation observed in the large PyMT tumours observed in mice receiving the high folic acid diet could be directly caused by folic acid, we treated primary cells from PyMT-induced tumours with folic acid for $12 \mathrm{~min}$ and evaluated the level of activated STAT3 (Figure 4). Folic acid was found to activate STAT3 at 300 and $500 \mu \mathrm{g} \mathrm{ml}^{-1}$ in cells isolated from three different tumours. In addition, the isolated cancer cells expressed murine FR, again confirming that this FR is expressed in PyMTinduced breast cancer cells.

FR expression is linked to tumour progression in the PyMT mouse model. To investigate when PyMT mice begin to express FR in the breast tumour tissue, mRNA and protein levels were examined in 3-9-week-old PyMT mice and compared with wt 


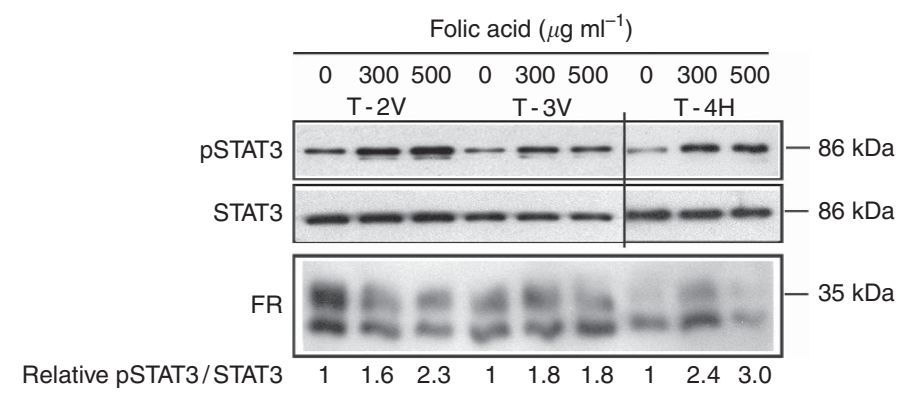

Figure 4. Folic acid activates STAT3 in PyMT primary cells. Primary cancer cells isolated from three individual PyMT tumours were treated with the indicated amounts of folic acid for $12 \mathrm{~min}$ and protein extracts were subjected to immunoblot analysis against the indicated proteins. The amount of total STAT3 protein was used as a loading control. Immunoblot densitometry was performed, and the pSTAT3/STAT3 ratio was determined. The PSTAT3/STAT3 ratio was set to 1 for the untreated control for each cell line.

A
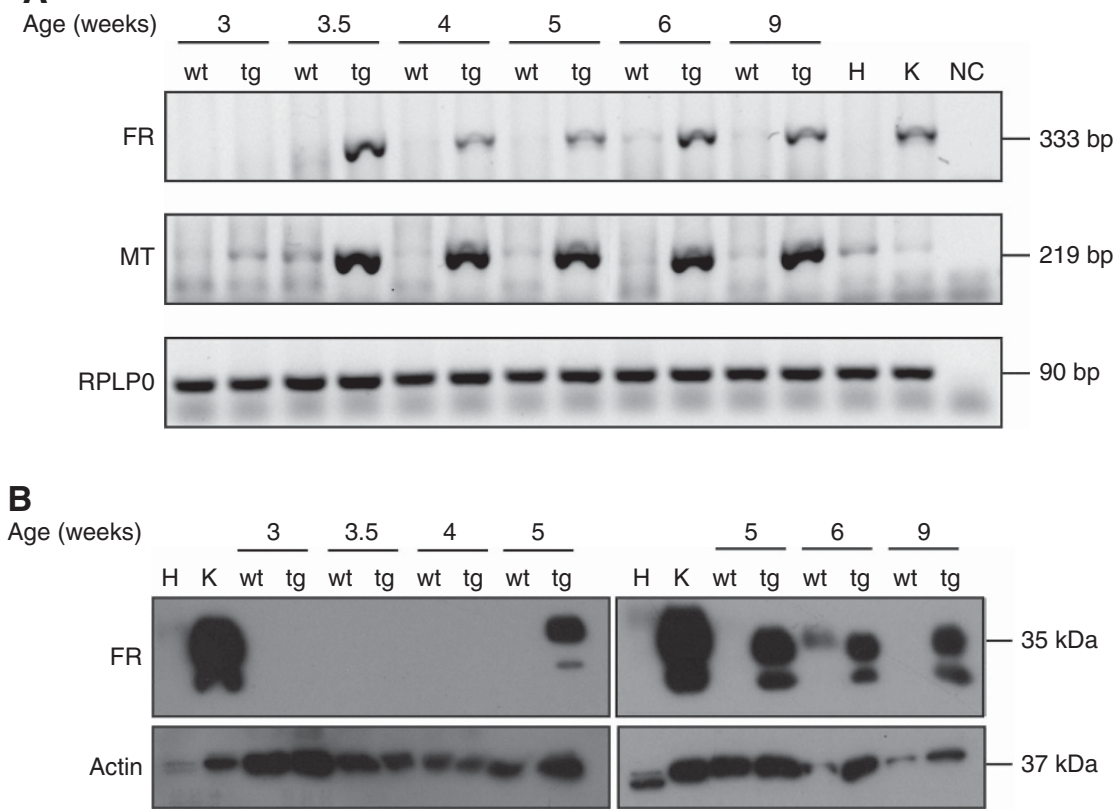

Figure 5. Folate receptor protein and mRNA levels in PyMT and wt breast tissues. Breast tissues dissected from wt FVB/N (wt) or PyMT transgenic female mice (tg) were recovered at the indicated time points and homogenised. Heart $(\mathrm{H})$ and kidney $(\mathrm{K})$ tissues were included as negative and positive controls for FR expression. (A) Reverse transcription-PCR (RT-PCR) was performed with RNA extracted from the indicated tissues using primers targeting murine FR, the MT oncogene and RPLPO, respectively. RPLPO was used as a control. (B) Immunoblot analysis was performed using antibodies raised against murine FR, or actin. Actin was used as a loading control. The sodium dodecyl sulphate-polyacrylamide gel electrophoresis (SDS-PAGE) for the FR blot was performed under non-reducing conditions. Two biologically independent RNA extractions were performed and each was subjected to two CDNA synthesis reactions. PCR experiments were repeated four times, and the immonoblot analyses were carried out at least three times with independent protein extractions.

$\mathrm{FVB} / \mathrm{N}$ littermates at the same age (Figures $5 \mathrm{~A}$ and $\mathrm{B}$ ). Concurrent bands from FR and MT mRNAs in the breast tissue from the transgenic PyMT mice from 3.5 weeks of age were observed (Figure 5A). A weak band corresponding to FR mRNA was observed in 6-week-old wt FVB/N mice. As expected, no MT mRNA was observed in wt FVB/ $\mathrm{N}$ mice, and the very faint bands detected in the mammary glands from 3.5-week-old wt FVB/N mice were also present in the heart and kidney and were considered unspecific.

To support these data, the protein levels of FR were examined by immunoblot analyses of protein extracts from the breast tissues from the same mice aged 3-9 weeks (Figure 5B). Folate receptor was detected in the breast tissue from PyMT mice that were 5, 6 and 9 weeks old, whereas no FR could be detected in the breast tissue from mice that were 3, 3.5 and 4 weeks old. Wild-type FVB/ $\mathrm{N}$ mice showed expression of FR only at 6 weeks of age, and this correlated with the observed low FR mRNA levels in the breast tissue from these mice. The lack of FR expression in breast tissue from the 9 -week-old wt FVB/N mice is further supported by data presented in Figure 2A.

We conclude that PyMT mice express the FR from 5 weeks of age, and the FR mRNA is present from 3.5 weeks, at the same time as the appearance of the oncogene MT mRNA. Contrary to that in the wt FVB/N mice, the expression of the FR is lower and limited to a short period around week 6 .

\section{DISCUSSION}

In the presented study, we investigated the effect of a high folic acid diet on tumour progression in the PyMT mouse breast cancer model. We found a 1.9-fold increase in the total tumour volume of 
individual mice in the group receiving the high folic acid diet. In addition, the number of tumours above 100 and $200 \mathrm{~mm}^{3}$ were increased by 1.9 - and 11 -fold, respectively. Especially the number of large tumours $\left(>200 \mathrm{~mm}^{3}\right)$ were increased, suggesting a direct effect of folic acid on tumour growth. Although we observed remarkable effects on tumorigenesis by high dietary levels of folic acid, the design of the study does not allow us to distinguish between hyperplastic lesions $v s$ those that are adenomas or cancers. As tumour progression in the PyMT mouse model develops within a short time frame, we decided to start the dietary intervention already at 3 weeks of age, although previous studies had shown no detection of hyperplasia before 4 weeks of age (Lin et al, 2003). It is thus likely that the intervention was started at approximately the same time as the initial formation of premalignant lesions. This is important as previous studies in a colon cancer mouse model have demonstrated that a high folic acid diet can cause the progression of already existing lesions, while it might prevent tumour formation before the establishment of neoplastic lesions (Song et al, 2000). However, in this previous study of colon cancer, a high folic acid diet $\left(8 \mathrm{mg} \mathrm{kg}^{-1}\right)$ was compared with a non-standard diet completely depleted of folic acid $\left(0 \mathrm{mg} \mathrm{kg}^{-1}\right)$. Although intestinal bacteria may synthesise small amounts of folate and thereby supply minimal requirements of folates due to the coprophagic nature of mice, prolonged exposure to this diet causes severe folate deficiency. This may, in turn, affect tumour growth in an unpredicted manner. The standard rodent diet in our study with $2.335 \mathrm{mg}$ folate per $\mathrm{kg}$ represents the basal dietary requirement for rodents (Song et al, 2000). The physiological concentrations of folates in rodents maintained on standard laboratory diet have previously been found to be $\sim 10$ times as high as normal human physiological levels (almost $250 \mathrm{~nm}$ for BalB/c mice compared with $\sim 20 \mathrm{~nm}$ for humans) (Leamon et al, 2008). Importantly, our study compared the standard rodent diet with a high folic acid diet, thereby demonstrating that excess folic acid is tumour promoting.

Several epidemiological studies have addressed a putative link between folic acid supplements and cancer incidence, but no clear correlation has been found. In 2007, Mason et al published a study suggesting an increase in the rate of colorectal cancer in the United States and Canada after the onset of folic acid fortification. Moreover, in a placebo-controlled study including patients previously diagnosed with adenomas in the large intestine, a daily intake of $1 \mathrm{mg}$ per day of folic acid corresponding to a 2.5 -fold RDA was associated with a significantly higher risk of developing three or more colorectal adenomas, and with the occurrence of prostate cancer (Cole et al, 2007). However, meta-analysis studies have failed to show any association between controlled folic acid supplements and risk of cancer, except from a positive association between folic acid and melanomas (Qin et al, 2013; Vollset et al, 2013). In contrast, a study from 2010 addressing the effect of micronutrients on postmenopausal breast cancer found a positive association between high dietary folate and the risk of oestrogen receptor- and progesterone receptor-positive breast cancer (Roswall et al, 2010).

We found in the present study that murine FR is highly expressed in transgenic tumour tissues but not in normal breast tissues of 9-week-old mice. This is in accordance with a gene array study identifying high levels of murine FR mRNAs in PyMT tumours with the size of $0.5-1 \mathrm{~cm}$ compared with breast tissue from FVB/N control mice (Herschkowitz et al, 2007). Although PyMT tumours express oestrogen and progesterone receptors in the initial phases of tumour development, these receptors are lost as the tumours progress to late carcinomas (Lin et al, 2003). Importantly, a thorough clinical study identified human $\mathrm{FR} \alpha$ as being overexpressed in triple-negative breast cancers (ER negative, $\mathrm{PR}$ negative and Her2/Neu negative), with high FR $\alpha$ expression being correlated with poor prognosis (Zhang et al, 2013). Although speculative at this point, it is possible that murine FR expressed in
PyMT tumours have a similar tumour-promoting effect as seen in human triple-negative breast cancers (Necela et al, 2015). In support of an important role of FR $\alpha$ in breast cancer development, siRNA-mediated FR $\alpha$ knockdown in human breast cancer cell lines was found to decrease survival of cultured tumour cells including T47D, MDA-MB231 and MDA-MB435, indicating a growthpromoting effect of $\mathrm{FR} \alpha$ (Jhaveri et al, 2004).

Although FR $\alpha$ has been found to mediate the uptake of folates by receptor-mediated endocytosis (Sabharanjak and Mayor, 2004), other studies suggest that $\mathrm{FR} \alpha$ may also be involved in signalling pathways because it co-immunoprecipitates with the Src family kinase (SFK) Lyn and the G-coupled protein $\mathrm{G} \alpha_{3}$ (Miotti et al, 2000). Moreover, the human FR variant FR $\gamma$ was recently found to be involved in folic acid-induced cSrc activation in human umbilical vein endothelial cells in culture (Lin et al, 2012). The interaction between the human FRs and SFKs and SFK activation are of interest because SFKs activated in breast cancer cells have been found to cause the activation of the STAT3 oncogene (Garcia et al, 2001). Moreover, in the PyMT mouse model, tumourigenesis is initiated by Src-mediated phosphorylation of the MT oncogene, which results in the activation of several oncogenic signalling pathways including STAT3 activation. It is therefore tempting to speculate that murine FR might promote tumourigenesis in the PyMT mouse model via interactions with SFKs. In agreement with this hypothesis, we found that the expression of murine FR mRNA and protein coincided with the MT mRNA expression, thereby confirming that murine FR is present in the early phase of premalignant PyMT lesions. However, future experiments using FR-knockout mice will be required to investigate the importance of murine FR in mediating tumour growth in this model.

To investigate if altered signalling pathways were responsible for folic acid-induced tumour growth in the PyMT mouse model, we investigated the expression of STAT3 and ERK1/2 previously found to be activated in this model (Flowers et al, 2010; Park et al, 2010). The fact that only few tumours displayed ERK1/2, activation at the early stage investigated in our study suggests that ERK1/2 contributes to tumourigenesis only in some individual tumours, and that the activation is not required for the general tumour induction capacity of PyMT. In contrast, a high expression and activation of STAT3 was seen in PyMT tumours, whereas a low expression and activation was seen in normal control FVB/N breast tissues. In addition, the highest STAT3 activation was seen in the larger tumours. Although we could not detect any direct effect of high folic acid diet on STAT3 activation in vivo, a higher level of STAT3 expression and STAT3 activation was seen in large tumours above $200 \mathrm{~mm}^{3}$ only present in the high folic acid diet group. However, as mice were not starved before the end of the experiment, differences in feeding just before the individual mice being killed may have affected the folate status in the tumours. In our study, activated STAT3 was only detected in PyMT breast tissues, and no activation was seen in wt FVB/N breast tissues of 9week-old mice. This is consistent with the previous findings that STAT3 is activated in several human breast cancers, and has been found to be activated following transformation of fibroblasts with MT protein in vitro (Garcia et al, 1997). Furthermore, a later study found that STAT3 activation could be inhibited by Src and JAK inhibitors in human breast cancer cell lines, suggesting a key role for Src in STAT3 activation in breast cancers (Garcia et al, 2001). Very recently, we have shown that folic acid can promote cell proliferation in FR $\alpha$-expressing HeLa cells (Hansen et al, 2015). In contrast, another study demonstrated that folic acid could inhibit colon cancer cell proliferation via the $\mathrm{FR} \alpha / \mathrm{c}-\mathrm{SRC} / \mathrm{ERK} 1 / 2$ pathway (Kuo et al, 2015). This indicates that folic acid can exert different cell-specific functions through the FR $\alpha$ depending on the presence of different signalling factors in the different cell types or tissues. 
In agreement with this hypothesis, it was very recently shown that folic acid can inhibit implanted colon cancer growth when folic acid was injected intraperitoneally in SCID mice (Kuo et al, 2015). The use of SCID mice and injected colon cells in addition to the intraperitoneal folic acid administration makes this system very different from spontaneous tumour formation and might explain the tumour-preventing effect seen in this study.

To further investigate a putative involvement of folic acid on increased STAT3 activation, primary PyMT cells were treated with folic acid in vitro. Here folic acid was found to activate STAT3 immediately after treatment, indicating that the STAT3 activation was independent of gene transcription. The STAT3 oncogene is considered an important molecular target in cancer therapy, as it causes increased cell proliferation, angiogenesis and inhibition of apoptosis (Yu et al, 2009; Jarnicki et al, 2010; Johnston and Grandis, 2011). Folic acid-induced STAT3 activation would thus offer an explanation for the folic acid-induced tumour growth seen in our study, even though the concentrations used were far greater by several orders of magnitude than what is observed physiologically. Therefore, further work will be required to establish the biological relevance of this observation.

In conclusion, we have found that dietary folic acid markedly promotes early tumour growth in PyMT breast cancer mouse model. To investigate the mechanisms behind this activation, we found that PyMT breast tumours expressed murine FR and that STAT3 was activated. Moreover, in primary cells derived from PyMT-induced tumours, folic acid may contribute directly to the activation of STAT3 through binding of the murine FR. The PyMT breast tumour mouse model can be used for analysing and exploiting FRs in cancers, in particular its role during the early development of breast tumours.

\section{ACKNOWLEDGEMENTS}

We thank Astrid Kühle and Dorte Hermansen for expert laboratory assistance, Dr Lars Engelholm for kindly donating the PyMT heterozygous male mice used for breeding and Dr Henrik Birn for kindly donating the anti-FR antibody. Support from the Arne Hansen Foundation, the AP Moller Foundation for the Advancement of Medical Science, Aarhus University and the Danish Cancer Society was highly appreciated.

\section{CONFLICT OF INTEREST}

The authors declare no conflict of interest.

\section{REFERENCES}

Birn H (2006) The kidney in vitamin B12 and folate homeostasis: characterization of receptors for tubular uptake of vitamins and carrier proteins. Am J Physiol Renal Physiol 291: F22-F36.

Birn H, Spiegelstein O, Christensen EI, Finnell RH (2005) Renal tubular reabsorption of folate mediated by folate binding protein. J Am Soc Nephrol 16: 608-615.

Brown D, Lydon J, McLaughlin M, Stuart-Tilley A, Tyszkowski R, Alper S (1996) Antigen retrieval in cryostat tissue sections and cultured cells by treatment with sodium dodecyl sulfate (SDS). Histochem Cell Biol 105: 261-267.

Bugge TH, Lund LR, Kombrinck KK, Nielsen BS, Holmback K, Drew AF, Flick MJ, Witte DP, Dano K, Degen JL (1998) Reduced metastasis of polyoma virus middle $\mathrm{T}$ antigen-induced mammary cancer in plasminogen-deficient mice. Oncogene 16: 3097-3104.

Chen Y-L, CHang M-C, Huang C-Y, Chinag Y-C, Lin H-W, Chen C-A, Hsieh C-Y, Cheng W-F (2012) Serous ovarian carcinoma patients with high alpha-folate receptor had reducing survival and cytotoxic chemoresponse. Mol Oncol 6: 360-369.

Cole BF, Baron JA, Sandler RS, Haile RW, Ahnen DJ, Bresalier RS, McKeown-Eyssen G, Summers RW, Rotstein RI, Burke CA, Snover DC, Church TR, Allen JI, Robertson DJ, Beck GJ, Bond JH, Byers T, Mandel JS, Mott LA, Pearson LH, Barry EL, Rees JR, Marcon N, Saibil F, Ueland PM, Greenberg ER (2007) Folic acid for the prevention of colorectal adenomas. JAMA 297: 2351-2359.

Corona G, Giannini F, Fabris M, Toffoli G, Boiocchi M (1998) Role of folate receptor and reduced folate carrier in the transport of 5-methyltetrahydrofolic acid in human ovarian carcinoma cells. Int J Cancer 75: 125-133.

Elnakat H, Gonit M, Salazar MD, Zhang J, Basrur V, Gunning W, Kamen B, Ratnam M (2009) Regulation of folate receptor internalization by protein kinase C alpha. Biochemistry 48: 8249-8260.

Elnakat H, Ratnam M (2004) Distribution, functionality and gene regulation of folate receptor isoforms: implications in targeted therapy. Adv Drug Deliv Rev 56: 1067-1084.

Finglas PM, Wright AJ, Wolfe CA, Hart DJ, Wright DM, Dainty JR (2003) Is there more to folates than neural-tube defects? Proc Nutr Soc 62: 591-598.

Flowers M, Schroeder JA, Borowsky AD, Besselsen DG, Thomson CA, Pandey R, Thompson PA (2010) Pilot study on the effects of dietary conjugated linoleic acid on tumorigenesis and gene expression in PyMT transgenic mice. Carcinogenesis 31: 1642-1649.

Fluck MM, Schaffhausen BS (2009) Lessons in signaling and tumorigenesis from polyomavirus middle T antigen. Microbiol Mol Biol Rev 73: 542-563.

Garcia R, Bowman TL, Niu G, Yu H, Minton S, Muro-Cacho CA, Cox CE, Falcone R, Fairclough R, Parsons S, Laudano A, Gazit A, Levitzki A, Kraker A, Jove R (2001) Constitutive activation of Stat3 by the Src and JAK tyrosine kinases participates in growth regulation of human breast carcinoma cells. Oncogene 20: 2499-2513.

Garcia R, Yu C, Hudnall A, Catlett R, Nelson K, Smithgall T, Fujita D, Ethier S, Jove R (1997) Constitutive activation of Stat 3 in fibroblasts transformed by diverse oncoproteins and in breast carcinoma cells. Cell Growth Differ 8: 1267-1276

Guo K, Li J, Tang JP, Tan CP, Hong CW, Al-Aidaroos AQ, Varghese L, Huang C, Zeng Q (2011) Targeting intracellular oncoproteins with antibody therapy or vaccination. Sci Transl Med 3: $99 \mathrm{ra} 85$.

Guy C, Cardiff RD, Muller WJ (1992) Induction of mammary tumors by expression of polyomavirus middle $\mathrm{T}$ oncogene: a transgenic mouse model for metastatic disease. Mol Cell Biol 12: 954-961.

Hansen MF, Greibe E, Skovbjerg S, Rohde S, Kristensen ACM, Jensen TR, Stentoft C, Kjær KH, Kronborg CS, Martensen PM (2015) Folic acid mediates activation of the pro-oncogene STAT3 via the folate receptor alpha. Cell Signal 27: 1356-1368.

Herschkowitz JI, Simin K, Weigman VJ, Mikaelian I, Usary J, Hu Z, Rasmussen KE, Jones LP, Assefnia S, Chandrasekharan S, Backlund MG, Yin Y, Khramtsov AI, Bastein R, Quackenbush J, Glazer RI, Brown PH, Green JE, Kopelovich L, Furth PA, Palazzo JP, Olopade OI, Bernard PS, Churchill GA, Van Dyke T, Perou CM (2007) Identification of conserved gene expression features between murine mammary carcinoma models and human breast tumors. Genome Biol. 8: R76.

Jarnicki A, Putoczki T, Ernst M (2010) STAT3: linking inflammation to epithelial cancer - more than a 'gut' feeling? Cell Div 5: 14.

Jhaveri MS, Rait AS, Chung KN, Trepel JB, Chang EH (2004) Antisense oligonucleotides targeted to the human alpha folate receptor inhibit breast cancer cell growth and sensitize the cells to doxorubicin treatment. $\mathrm{Mol}$ Cancer Ther 3: 1505-1512.

Johnston PA, Grandis JR (2011) STAT3 signaling: anticancer strategies and challenges. Mol Interv 11: 18-26.

Kamen BA, Smith AK (2012) Farletuzumap, an anti-folate receptor a antibody, does not block binding of folate or anti-folates to receptor nor does it alter the potency of anti-folates in vitro. Cancer Chemother Pharmacol 70: 113-120.

Kamen BA, Wang MT, Streckfuss AJ, Peryea X, Anderson RG (1988) Delivery of folates to the cytoplasm of MA104 cells is mediated by a surface membrane receptor that recycles. J Biol Chem 263: 13602-13609.

Kelemen LE (2006) The role of folate receptor $\alpha$ in cancer development, progression and treatment: cause, consequence or innocent bystander? Int J Cancer 119: 243-250.

Kobel M, Madore J, Ramus SJ, Clarke BA, Pharoah PDP, Deen S, Bowtell DD, Odunsi K, Menon U, Morrison C, Lele S, Bshara W, Sucheston L, Beckmann MW, Hein A, Thiel FC, Hartmann A, Wachter DL, Anglesio MS, Hogdall E, Jensen A, Hogdall C, Kalli KR, Fridley BL, Keeney GL, Fogarty 
ZC, Vierkant RA, Liu S, Cho S, Nelson G, Ghatage P, Gentry-Maharaj A, Gayther SA, Benjamin E, Widschwendter M, Intermaggio MP, Rosen B, Bernardini MQ, Mackay H, Oza A, Shaw P, Jimenez-Linan M, Driver KE, Alsop J, Mack M, Koziak JM, Steed H, Ewanowich C, DeFazio A, Chenevix-Trench G, Fereday S, Gao B, Johnatty SE, George J, Galletta L, Group AS, Goode EL, Kjar SK, Huntsman DG, Fasching PA, Moysich KB, Brenton JD, Kelemen LE (2014) Evidence for a time-dependent association between FOLR1 expression and survival from ovarian carcinoma: implications for clinical testing. An Ovarian Tumour Tissue Analysis Consortium Study. Br J Cancer 111: 2297-2307.

Kuo C-T, Chang C, Lee W-S (2015) Folic acid inhibits COLO-205 colon cancer cell proliferation through activating the FR $\alpha / \mathrm{c}-\mathrm{SRC} / \mathrm{ERK} 1 / 2 / \mathrm{NF \kappa B} /$ TP53 pathway: in vitro and in vivo studies. Sci Rep 5: 11187.

Leamon CP, Reddy JA, Dorton R, Bloomfield A, Emsweller K, Nikki Parker N, Westrick E (2008) Impact of high and low folate diets on tissue folate receptor levels and antitumor responses toward folate-drug conjugates. J Pharmacol Exp Ther 327: 918-925.

Lin EY, Jones JG, Li P, Zhu L, Whitney KD, Muller WJ, Pollard JW (2003) Progression to malignancy in the polyoma middle $\mathrm{T}$ oncoprotein mouse breast cancer model provides a reliable model for human diseases. Am J Pathol 163: 2113-2126.

Lin SY, Lee WR, Su YF, Hsu SP, Lin HC, Ho PY, Hou TC, Chou YP, Kuo CT, Lee WS (2012) Folic acid inhibits endothelial cell proliferation through activating the $\mathrm{cSrc} / \mathrm{ERK} 2 / \mathrm{NF}-\mathrm{kappaB} / \mathrm{p} 53$ pathway mediated by folic acid receptor. Angiogenesis 15: 671-683.

Lucock M (2000) Folic acid: nutritional biochemistry, molecular biology, and role in disease processes. Mol Genet Metabol 71: 121-138.

Mason JB, Dickstein A, Jacques PF, Haggarty P, Selhub J, Dallal G, Rosenberg IH (2007) A temporal association between folic acid fortification and an increase in colorectal cancer rates may be illuminating important biological principles: a hypothesis. Cancer Epidemiol Biomarkers Prev 16: 1325-1329.

Miller JW, Borowsky AD, Marple TC, McGodrick ET, Dillard-Telm L, Young LDT, Green R (2008) Folate, DNA methylation, and mouse models of breast tumorigenesis. Nutr Rev. 66(Suppl 1): S59-S64.

Miotti S, Bagnoli M, Tomassetti A, Colnaghi MI, Canevari S (2000) Interaction of folate receptor with signaling molecules lyn and $\mathrm{G}(\mathrm{alpha})$ (i-3) in detergent-resistant complexes from the ovary carcinoma cell line IGROV1. J Cell Sci 113(Part 1): 349-357.

Necela BM, Crozier JA, Andorfer CA, Lewis-Tuffin L, Kachergus JM, Geiger XJ, Kalari KR, Serie DJ, Sun Z, Moreno-Aspita A, O'Shannessy DJ, Maltzman JD, McCullough AE, Pockaj BA, Cunliffe HE, Ballmann KV, Thompson EA, Perez EA (2015) Folate Receptor-alpha (FOLR1) expression and function in triple negative tumors. PLoS One 10: e0122209.

Park J, Kusminski CM, Chua SC, Scherer PE (2010) Leptin receptor signaling supports cancer cell metabolism through suppression of mitochondrial respiration in vivo. Am J Pathol 177: 3133-3144.
Parker N, Turk MJ, Westrick E, Lewis JD, Low PS, Leamon CP (2005) Folate receptor expression in carcinomas and normal tissues determined by quantitative radioligand binding assay. Anal Biochem 338: 284-293.

Qin X, Cui Y, Shen L, Sun N, Zhang Y, Li J, Xu X, Wang B, Xu X, Huo Y, Wang X (2013) Folic acid supplementation and cancer risk: a meta-analysis of randomized controlled trials. Int J Cancer 133: 1033-1041.

Roswall N, Olsen A, Christensen J, Dragsted LO, Overvad K, Tjonneland A (2010) Micronutrient intake and breast cancer characteristics among postmenopausal women. Eur J Cancer Prev 19: 360-365.

Sabharanjak S, Mayor S (2004) Folate receptor endocytosis and trafficking. Adv Drug Deliv Rev 56: 1099-1109.

Smart EJ, Mineo C, Anderson RG (1996) Clustered folate receptors deliver 5-methyltetrahydrofolate to cytoplasm of MA104 cells. J Cell Biol 134: 1169-1177.

Song J, Sohn K-J, Medline A, Ash C, Gallinger S, Kim Y-I (2000) Chemopreventive effects of dietary folate on intestinal polyps in Apc + I - Msh2 - I - mice. Cancer Res 60: 3191-3199.

Strickland KC, Krupenko NI, Krupenko SA (2013) Molecular mechanisms underlying the potentially adverse effects of folate. Clin Chem Lab Med 51: 607-616.

Vollset SE, Clarke R, Lewington S, Ebbing M, Halsey J, Lonn E, Armitage J, Manson JE, Hankey GJ, Spence JD, Galan P, Bonaa KH, Jamison R, Gaziano JM, Guarino P, Baron JA, Logan RF, Giovannucci EL, den Heijer M, Ueland PM, Bennett D, Collins R, Peto R. Collaboration BVTT (2013) Effects of folic acid supplementation on overall and site-specific cancer incidence during the randomised trials: meta-analyses of data on 50000 individuals. Lancet 381: 1029-1036.

Yu H, Pardoll D, Jove R (2009) STATs in cancer inflammation and immunity: a leading role for STAT3. Nat Rev Cancer 9: 798-809.

Zhang Z, Wang J, Tacha DE, Li P, Bremer RE, Chen H, Wei B, Xiao X, Da J, Skinner K, Hicks DG, Bu H, Tang P (2013) Folate receptor alpha associated with triple-negative breast cancer and poor prognosis. Arch Pathol Lab Med 138: 890-895.

Zhao R, Diop-Bove N, Visentin M, Goldman ID (2011) Mechanisms of membrane transport of folates into cells and across epithelia. Аnnu Rev Nutr 31: 177-201.

Zhao R, Gao F, Hanscom M, Goldman ID (2004) A prominent low-pH methotrexate transport activity in human solid tumors: contribution to the preservation of methotrexate pharmacologic activity in HeLa cells lacking the reduced folate carrier. Clin Cancer Res 10: 718-727.

Zhao X, Li H, Lee RJ (2008) Targeted drug delivery via folate receptors. Expert Opin Drug Deliv 5: 309-319.

This work is published under the standard license to publish agreement. After 12 months the work will become freely available and the license terms will switch to a Creative Commons AttributionNonCommercial-Share Alike 4.0 Unported License. 